\title{
Making Eco-Bricks as a Solution to Environmental Problems through Empowering Creative Children: A Case Study in Baruga District, Kendari City
}

\author{
Farida Wardani ${ }^{1}$, Nurul Khotimah ${ }^{2}$ \\ 1,2Universitas Negeri Yogyakarta, Indonesia \\ Email: faridawardani.2019@student.uny.ac.id
}

\begin{abstract}
Garbage is one of the complex problems faced by both developing and developed countries in the world. The waste problem is a common problem and has become a universal phenomenon in various countries in the world. This research uses qualitative research with a descriptive analysis approach. The data used are primary data collected from community-based empowerment activities in the Baruga sub-district, Kendari city. From this research, it can be seen that making eco-bricks can be used as a solution to the use of plastic waste, which is very much in the Baruga sub-district, Kendari City, through creative child empowerment activities. To make products using eco-bricks, glue for PVC plastics is not recommended because the plastic bottles used as eco-bricks are PET plastic, so they are unsuitable if glued with PVC glue.
\end{abstract}

Keywords: Plastic, Eco-Brick, Creative Children, Empowerment.

\section{A. INTRODUCTION}

According to the above definition, waste is the remains of everyday human activities, and natural processes in solid form under Article 1 of Law No 18 of the Year 2008 concerning waste management. The degree of public health is determined by the conditions of the host, the agent (cause of disease), and the environment (Ali, Masri, Muhamad \& Hamidon, 2020). Environmental factors are a determining element of public health. If there is a change in the environment around humans, there will be a change in the environmental health condition of the community (Apriyani, Putri \& Wibowo, 2020). Environmental factors and behavioural factors greatly influence public health, so it needs serious attention. Healthy behaviour factors are expected to maintain, improve health and protect themselves from disease threats, while a healthy environment is expected to create a conducive, pollution-free, residential environment (Asih \& Fitriani, 2018).

Plastic is a recycled material or material that can be recycled, so that's why there are many ways of processing plastics. In addition, plastic is also a chemical that is difficult to degrade or decompose by nature; it takes hundreds or even thousands of years to decompose plastic (Batubara \& Hamdani, 2019).

Plastics are used extensively in different types of life requirements. They range from food wrapping to automotive supplies. Plastic is the most popular material for the manufacture of automotive elements as well as metal, such as iron 
(Cahyadi, 2019). Plastic waste which cannot be naturally decomposed is the most important problem with plastics. Cleaning plastic waste out of the face of the earth takes a very long time. In addition, it is almost uncontrollable to use plastic (Chang \& Huang, 2016). The air temperature of plastics is also warmer day after day, due to the non-porous nature of the polymer. Currently, most products are produced without considering where they are used. In a certain period called "planted obsolescence, many products are also designed to fail." The cause behind the overflow of landfills, plastic islands and a flag such as packaging, packaging and products that obscure the regional ecosystems is the design philosophy (Chien, $\mathrm{Lu}$, Liou \& Huang, 2012).

Many companies need massive investment and restructuring, including production, material sourcing and the implementation of new systems for product absorption in order to set up a plastic waste treatment system. Healthy and healthy waste management can be daunting (Cusido, Devant \& Arteaga, 1996). Today, waste is a severe problem of the environment worldwide and is very closely related to everyday human life. As a party that produces waste, no one can be separated from the problem of waste (Dolores, Lasco, Bertiz \& Lamar, 2020). Thus, the problem of waste is a matter of public perception of waste.

Based on the Kendari City Sanitation and Gardening Office data, the volume of municipal waste in 2020 is around 79,579,470 kg of waste per month. This amount does not include the waste that does not enter the Final Waste Disposal Site (TPAS) or the landfill that the Kendari City Government does not accommodate because the Kendari city government, through the Sanitation Office, is only able to transport $60 \%$ of the waste. The limited capacity of the city government in waste management should be supported by community efforts to reduce the amount of waste available (Fauzi, Sumiarsih, Adriman \& Hasibuan, 2020).

In terms of quantity and type, waste becomes a problem increasing day by day in line with the increasing population, activity level, lifestyle, socioeconomic level, and technological advances (Frankson, 2016). The plastic waste that is dangerous and difficult to managed remains one of the factors causing environmental damage which remains a major problem for Indonesians (Furuta, Nakao \& Katsuki, 1993). For plastic bag waste, which the Community demands greatly, it requires decomposition in tens or even hundreds of years (Jiang, Liu, Wang \& Chen, 2018). Plastic waste that bacteria cannot break down is a severe problem for soil pollution. It would be nice if plastic waste can be used again by recycling and making new products. The current management of plastic waste management has not been effective; many people dispose of waste without paying attention to the category (Ingunza, Lima \& Araújo, 2013).

Behaviour is an attitude born as a result of the interaction between humans and the environment (Narto \& Suparno, 2020). The behaviour of individuals and society can affect environmental conditions, and people's awareness can influence it (Suminto, 2017). Research in Daha District found that one of the factors that influence waste management behaviour is the community's level of education and knowledge 
about local regulations regarding waste (Lin \& Chang, 2009). About 80\% of homemakers dispose of plastic waste in the garden and burn plastic waste around their house (Nasichah, 2019). Housewives, about 75\% of whom work as farmers, are often seen carrying drinks using used mineral water bottles (Magudeswaran, 2018). This study aims to determine the relationship between the level of knowledge of homemakers and the behaviour of managing plastic waste (Simon, 2019).

\section{B. METHOD}

This research is a qualitative type with a descriptive analysis approach. The data collected is primary data collected from the empowerment activities of community children in the Baruga sub-district, Kendari city. This program was initiated by collaborating with the local community, the head of the PKK RT, then conveying the technical activities that we will carry out, namely in the form of direct socialization to the community regarding environmentally friendly plastic waste management (Eco-Bricks). The implementation stage is carried out by socializing and explaining plastic waste, its impact on the environment and environmentally friendly management methods and training in managing plastic waste into valuable products, adding value, and being safe for the environment. It is a follow-up and controlling process at this stage, and we are following up on the plastic waste management that has been carried out. Besides that, at this stage, it also explains the advantages and economic value of products made from plastic waste. Children are expected to understand and practice how to manage plastic waste that is environmentally friendly and can socialize it to the surrounding community.

\section{RESULT AND DISCUSSION}

\section{Eco-Bricks Making}

Making eco-bricks is not tricky; it only requires patience and a little effort. In general, the steps for making an eco-brick are as follows: 1). Collecting used plastic bottles, such as used beverage packaging bottles (for example, mineral water), used cooking oil bottles and so on. Then wash it clean, then dry it; 2). Collect various kinds of plastic packaging, such as instant noodle packaging, instant drinks, plastic wrapping, plastic bags, etc. It must be ensured that these plastics are free from all types of food (left in them), dry and not mixed with other materials (clips, threads, paper, etc.); 3) Putting all types of plastic in point 2 into plastic bottles in point 1;4) Should not be mixed with paper, glass, metal, sharp objects and other materials other than plastic; 5) The plastic materials put in a plastic bottle must be compressed until they are very compact and fill the entire space in the plastic bottle; 6) How to compact it by using a tool made of bamboo or wood (such as bamboo or wooden sticks); 7) If you want to make something with the results of this eco-brick, for example making tables, chairs, or other objects, then you can use bottles of the same size, or even of the same type and brand, making it easier to arrange; 8) If you want a colourful result, the plastic packaging arranged in it can be arranged in such a way as to produce the desired colour. You can also wrap a plastic bottle with coloured cellophane / adhesive 
tape; 9) After all the plastic bottles are filled with plastic packages until they are solid, the plastic bottles are ready to be arranged and combined into other objects, such as tables, chairs, even walls and floors of stages, room dividers and many others; and 10) To glue one bottle to another bottle, adhesive glue or cement/gibs can be used. To hold them firmly, the bottles are tied tightly using string or thread. The use of raffia ropes will provide a good colour effect while reducing plastic waste from other types.

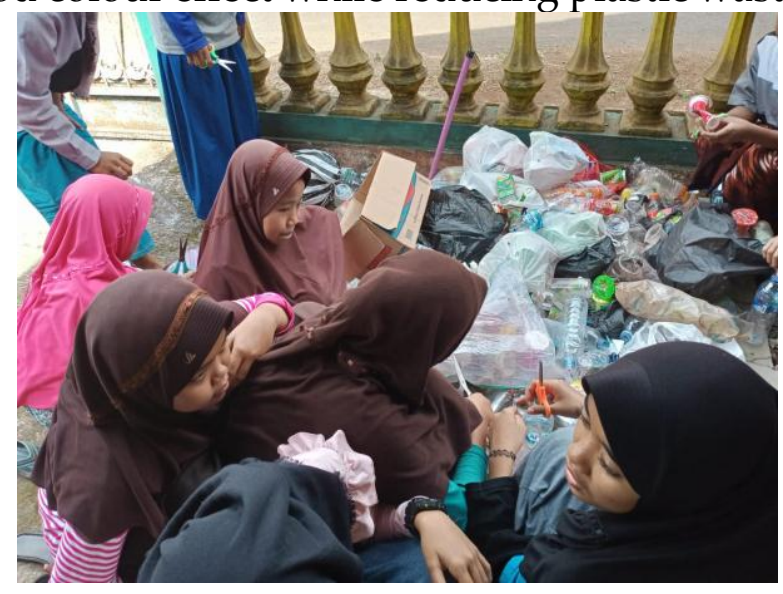

Source: Personal Documents

Figure 1. Eco-Brick Making in Creative Children Activities

Eco-bricks are a precious step forward in this transition. All technical nutrient cycles are captured by Ecobricks and non biologically degradable materials. Ecobricks enable designers to begin with the shaping of a cradle-to-cradle design. Prior consideration and planning allows the production of their products quickly and efficiently or also called Ecobrickable products (Yusri, Kamarudin, Saman \& Tutur, 2018). There are no official Ecobrickable products licenses, certificates or tests. This is design goodwill that is expected to save human life from plastic waste. Something has shifted here. Garbage, the use of plastics, which previously only been treated or handled by certain people (scavengers, people from lower classes, dirty and dark from various places), are now changing. Through eco-bricks, more people, more groups, no matter what social class they are, are becoming interested in working on plastic waste, especially those used in everyday life.

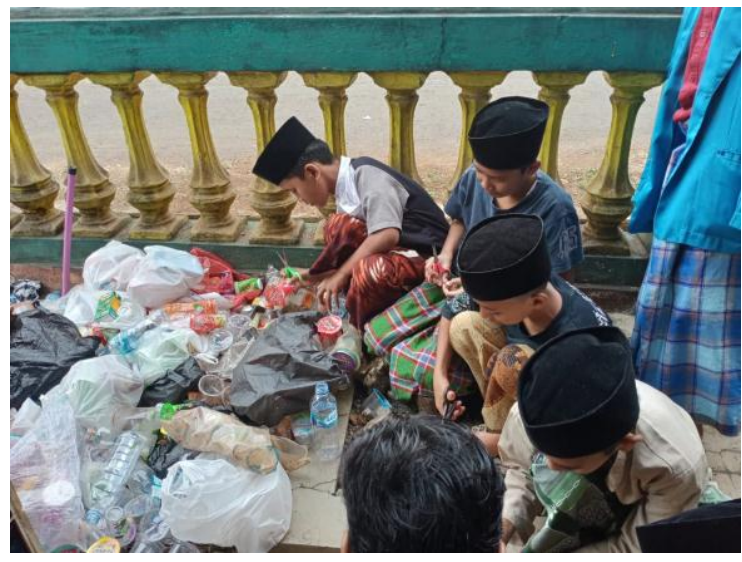

Figure 2. Plastic Sorting for Eco-Brick Contents

Source: Personal Documents

IJSOC (ㅇ) 2021

http://iisoc.goacademica.com 
Not only that, the most important and comforting thing is that people are starting to understand why we need eco-bricks. What is the basis and philosophy behind doing this hard work? More comprehensive knowledge about plastics, facts from plastic production, about this recycling problem, what are the dangers when we do things wrong with plastics, what are the effects to our environment if we are not aware, what will happen in the near and term-long if we don't care about them, how we need to change our lifestyle and our consumption behaviour, and what can we do with the plastics or waste used and even make them part of the solution.

That is the target. Not only how to manage plastics that have been continuously consumed, not only with aspirations of building or forming something with eco-bricks but about reducing plastic consumption and not using it as much as possible. And how to build awareness en masse, become a community movement in all lines and paths, because making eco-bricks does not require special skills, and is free of charge because it departs from used daily consumption, can be done at any time, and can also be done together or alone while doing other daily activities, while filling the time. Not just avoiding chemicals and making sure to consume everything healthier and more natural, but the reason is that these products are almost always packed in plastic wrap, which is difficult for us to eco-bricks: shampoo bottles, toothpaste tubes, liquid soap, and so on.

Plastics should be removed or treated as best as possible or put in the right place. Storing plastic is equivalent to reducing the effects of toxins that spread and damage the lives of living things. If stored in a sunprotected place, PET bottles will last for 300-500 years. Ecobricks permit us in circles to change the line of pollution products. Some Ecobrickables guidelines are: (1) There are no substances in the product that over time would corrode plastic PET. (2) The product can be mounted/cut down in components which fit into a standard PET bottle of $22 \mathrm{~mm}$ diameter neck (class A ecobrick). (3) There are no protrusions / sharp forms in the product that can puncture from inside a person working on the Ecobrick while packaged (e.g. glass, metal); (4) The product does not contain reactive chemicals, or if so, this component is marked as un-ecobrickable. (5) The product does not contain paper, liquids or materials other than plastics. (6) The product can fit in the neck/plane with a diameter or size of $10-20 \mathrm{~cm}$ (Ecobrick Class B). The results of the eco brick formation provide results that can be used in everyday life.

Plastic is a hard waste that naturally breaks down, and for years it has been a dilemma. Scientists, environmentalists and ecologists have been trying to solve the plastic waste problem in various ways. Ecobrick is a creativity in plastic waste handling. It does not work to destroy plastic wastes, but instead extends the life of such plastics and makes them useful to people in general. The Ecobrick production in the wider community is still not very popular. Most people still treat household-made plastic waste, pollute the environment, waterways and pollute everyday life unconsciously. For this reason, there is a need for more intensive socialization regarding creative processing efforts for plastic waste. I am starting from household plastic waste. With a bit of effort, one crucial problem will unravel little by little. 


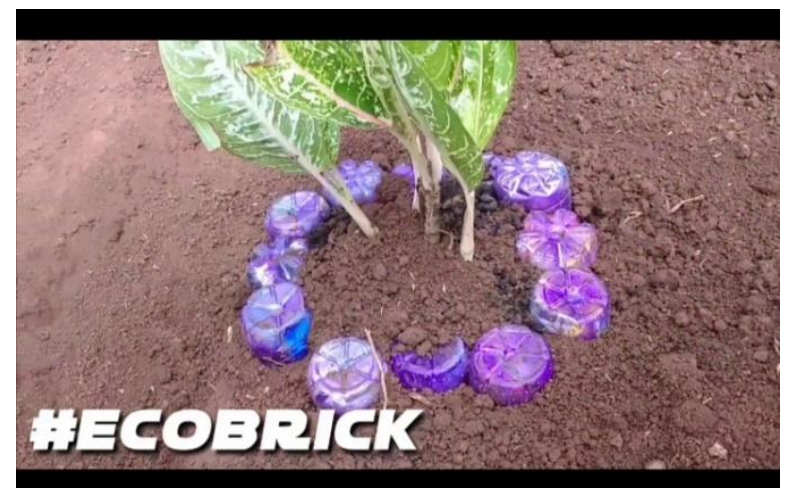

Figure 3. Examples of Eco-Bricks Use

Source: Personal Documents

Making eco-bricks routine once a week or two when there is a lot of plastic waste, that's when the awareness grows and concerns arise: how difficult it is to put a plastic spoon in a bottle, how hard it is to compact styrofoam from the used food wrappers of one of the restaurants, it's hard to put plastic mica from used cable wrappers data or audio cables, the difficulty of eco bricking used toothpaste tubes, or some plastic-coated paper bottles such as milk cartons, which even have metal or metal parts on the lid, or a little plastic in the hole.

There is an awareness that some packages are complicated to work with because they contain mixed ingredients and are difficult to eco brick. At the same time, eco-bricks are the only solution to trapping plastics, so they don't roam the environment and the earth. Or make eco-bricks a habit. Only then is the awareness of plastic consumption and the need to protect the environment from toxic plastics. Meanwhile, it is clear that entrusting trash bins, garbage trucks, garbage bins, will not affect anything; it will even end more horribly.

Even when trying to recycle, it is nothing more than delaying the final arrival of plastic waste to the process of contaminating soil, air, water and plants and forests and food and ourselves and our bodies or pregnant women or newborns or babies who are about to be born. Only from household waste, which is used alone, starts there, we will be more aware and careful and reduce our plastic consumption.

\section{The Urgency of Eco-Brick Making}

The petrochemical plastics are manufactured. These substances are not ecologically suitable. Scientific studies show that these chemicals are toxic to people; this is known when plastic burning is smelled. When these substances dissolve into soil and water and air over time, they are absorbed in human-absorbed plants and animals that cause damage to the soil, water and air. Dispersed, burned or disposed plastic waste produces toxic substances. Even the TPST (Final Waste Disposal Site) engineering cannot be a successful solution. These chemicals will eventually enter the biosphere and influence livestock and human life within ten years or even hundred years.

Plastics are not biodegrading; they are photodegrading. So the plastic breaks down into small pieces and then soaks into the ground or water. Because the pieces 
are so small, the plants, fish and animals we eat are easily absorbed. Wissenschaftler are beginning to see how the oceans are currently filled with plastic and other nonbiodegradable materials. Many studies have demonstrated adverse effects on marine and environmental animals. Researchers found that the chilling effect on man's body is the absorption into the human body of the chemicals that make-up plastics. In the United States and Europe, chemicals such as Biphenyl A and Phalates are now banned. But in the Philippines and in other Asian countries the chemical is still common. Even small numbers of this chemical cause allergy, hormonal imbalances, cancer and acut poisoning to humans. This chemical causes allergies. The most vulnerable to unfavorable effects are young children. Petrochemicals combine to form dioxins when plastic is burnished. Dioxins pollute air through smoking and earth and water through the soil. Dioxins are destructive poisons.

\section{CONCLUSION}

From the research results, it can be seen that making Ecobricks can be used as a solution to the use of plastic waste, which is very much in the Baruga sub-district, Kendari City, through creative child empowerment activities. Under any temperature conditions, the eco brick will remain solid. To make products using eco-bricks, glue for PVC plastics is not recommended because the plastic bottles used as eco-bricks are PET plastic, so they are unsuitable if glued with PVC glue. By doing so, it can be concluded that eco-bricks will be a sturdy product in any weather conditions and will continue to smear each other if they are glued together with silica glue.

\section{REFERENCES}

1. Ali, R., Marsi, N., Kamal, N. F. I. M., Muhamad, M. S., Sunar, N. M., Harun, H., ... \& Hamidon, N. (2020). A Study on the Characteristic of an Eco-Brick as a Replacement to the Conventional Brick. Progress in Engineering Application and Technology, 1(1), 22-29.

2. Apriyani, A., Putri, M. M., \& Wibowo, S. Y. (2020). Pemanfaatan sampah plastik menjadi ecobrick. Masyarakat Berdaya dan Inovasi, 1(1), 48-50.

3. Asih, H. M., \& Fitriani, S. (2018). Penyusunan standard operating procedure (SOP) produksi inovasi ecobrick. Jurnal Ilmiah Teknik Industri, 17(2), 144-150.

4. Batubara, A. R., \& Hamdani, A. R. (2019, August). International Course of One Asia Community in 2019 "Tongbu for Eco-Brick". International Conference of One Asia Community (Vol. 1, No. 1, pp. 88-90).

5. Cahyadi Husadha, C. H. (2019). Ecobrick sebagai Sarana Pengembangan Diri Berbasis Ecopreneurship di Sekolah Dasar. DWIJA CENDEKIA: Jurnal Riset Pedagogik, 3(1), 93-101.

6. Chang, M. Y., \& Huang, W. J. (2016). Characterization of Solid Silicone Fertilizer Produced by Hydrothermal Processes from Silicon-containing Biomasses. Int. J. Environ. Agric. Res., 2.

7. Chien, C. C., Lu, Y. S., Liou, Y. J., \& Huang, W. J. (2012). Application of waste bamboo materials on produced eco-brick. Journal of Shanghai Jiaotong University 
(Science), 17(3), 380-384.

8. Cusido, J. A., Devant, M., Celebrovsky, M., Riba, J., \& Arteaga, F. (1996). Ecobrick (R): A new ceramic material for solar buildings. Renewable energy, 8(1-4), 327-330.

9. Dolores, A. J. S., Lasco, J. D., Bertiz, T. M., \& Lamar, K. M. (2020). Compressive Strength and Bulk Density of Concrete Hollow Blocks (CHB) Infused with Lowdensity Polyethylene (LDPE) Pellets. Civil Engineering Journal, 6(10), 1932-1943.

10. Fauzi, M., Sumiarsih, E., Adriman, A., Rusliadi, R., \& Hasibuan, I. F. (2020). Pemberdayaan Masyarakat Melalui Pelatihan Pembuatan Eco-brick Sebagai Upaya Mengurangi Sampah Plastik di Kecamatan Bunga Raya. Riau Journal of Empowerment, 3(2), 87-96.

11. Frankson, L. (2016). New-School Construction: Bricks, Mortars \& ABTs. Images, 41(2), 55-57.

12. Furuta, S., Nakao, H., \& Katsuki, H. (1993). Preparation of Porous Ceramics from Industrial Waste Silica Mineral. Journal of materials science letters, 12(5), 286-287.

13. Ingunza, M. D. P. D., Lima, A. D., \& Araújo, A. L. C. (2013). Use of Septic Tank Sludge as Raw Material in the Manufacture of Bricks. In Advanced Materials Research (Vol. 712, pp. 921-924). Trans Tech Publications Ltd.

14. Jiang, L., Li, Z., Liu, Y., Wang, W., Zhang, Y., \& Chen, Y. F. (2018). Comparison of seismic performance between thermal insulation concrete and regular concrete shear walls. Materials Testing, 60(3), 293-300.

15. Lin, K. L. (2007). The heating temperature of thin-film transistor liquid crystal display (TFT-LCD) Optical Waste Glass as a Partial Substitute Partial for Clay in eco-brick. Journal of Cleaner Production, 15(18), 1755-1759.

16. Lin, K. L., Chang, W. K., Chang, T. C., Lee, C. H., \& Lin, C. H. (2009). Recycling thin film transistor liquid crystal display (TFT -LCD) waste glass produced as glass-ceramics. Journal of Cleaner Production, 17(16), 1499-1503.

17. Magudeaswaran, P., \& AS, H. (2018). Development of Eco Brick and Concrete with the partial replacement of cow dung. Development, 6(5).

18. Narto, S., \& Suparno, B. A. (2020). Evaluasi Program Corporate Social Responsibility Pelatihan Ecobrick dalam Mengelola Sampah Plastik. Jurnal Ilmu Komunikasi, 17(3), 295-306.

19. Nasichah, N. (2019). Peran Sanggar Hijau Indonesia Dalam Mengembangkan Sikap Peduli Lingkungan Peserta Didik Melalui Program Eco-brick di SMA Negeri Mojoagung Jombang. Kajian Moral dan Kewarganegaraan, 7(2).

20. Simon, E. (2019). Plastics from a whole planet perspective. Field Actions Science Reports. The journal of field actions, (Special Issue 19).

21. Suminto, S. (2017). Ecobrick: solusi cerdas dan kreatif untuk mengatasi sampah plastik. Productum: Jurnal Desain Produk (Pengetahuan dan Perancangan Produk), 3(1), 26-34.

22. Yusri, N. N., Kamaruddin, K., Saman, H., \& Tutur, N. (2018). Strength performance of sustainable mortar containing recycle sewage sludge ash (SSA). Scientific Research Journal, 15(1), 47-58. 